\title{
MEDICINE AT THE GOURT OF LOUIS XIV
}

by

\section{LEON BERNARD}

WHEN we think at all of Louis XIV, it is generally in terms of the gorgeous portraiture of Rigaud and the vivid word-pictures of Saint-Simon. We see the Grand Monarque in his ermine-lined robes of State, sceptre in hand, arm on hip, gazing out on the world with affable condescension and consummate pose. We see the epitome of majesty: grace, dignity, command.

It is a disillusioning experience to turn from this figure to the Louis XIV as seen in private life by his doctors. A new and disconcertingly human Sun King emerges. One begins to discern a man plagued by chronic infirmities of all kinds; pestered by doctors and surgeons; subjected to incredible purges, enemas, and emetics; treated often like a small boy who really does not know what is good for him; occasionally driven to rebellion but on the whole remarkably tolerant of his medical advisors.

In the seventeenth century, it was the fortunate man who could not afford medical treatment. The higher one's station in life the greater became one's medical woes. One of the most scathing critics of seventeenth-century doctors (but unfortunately a hypochondriac who could not leave doctors alone), the famous Madame de Sévigné, recognized this truth. When her three-year-old grandson fell sick and, to her dismay, was promptly bled, Sévigné commented wryly: 'I fear that they do this to our child so as to honour him, as they do to the children of the King. ....'1

Since the King's station was the highest in France, it follows that he had more to contend with from the medical profession than anyone else. This can be easily confirmed by a glance at the Fournal de la Santé $d u$ Roi, a unique record of the health of the King from I647 to I 7 I I kept by three premier médecins in succession. Among the recognizable ailments ascribed to the King are rheumatism, vapours, humours, fistula, insomnia, indigestion, fluxes, headaches, chronic fevers, anthrax, melancholy, urinary difficulties, night sweats, vertigo, erysipelas, colds, colic, bile, acid mouth, chronic toothaches, and, inevitably, a great deal of gout. It is true that none of these is particularly serious, and spread over a seventy-seven-year life-span they are not necessarily indicative of chronically bad health. (Finally the King died of a gangrenous leg.) What is striking, however, is the frequency of these complaints and the drastic treatments which even the most minor ailment provoked. Every royal evacuation was analysed by the King's doctor and described in a language which almost makes Molière prosaic. Too often the analysis led to the solemn conclusion that still another variant of the 'bouillon purgatif' was called for. To cite just one example, in one seven-week period the King was given a purge every day but two; 'good results' 


\section{Leon Bernard}

were obtained 'five, six, or seven times a day without [the King] being weakened', the doctor wrote triumphantly. ${ }^{2}$ One of the royal doctors was satisfied only when the King was purged to the point of passing blood; on 6 July I 705 we read that 'la selle rouge' was obtained after 'treize selles prodigieuses'. ${ }^{3}$

Responsible for the King's health during most of his reign of seventy-two years (I643-I 7 I5), and thus the most prestigious doctors in France, were three men: Vallot, Daquin, and Fagon. ${ }^{4}$ Unlike most Court functionaries, they owed their positions mainly to demonstrated ability in their profession, although some political ability was undoubtedly necessary. Their backgrounds were thoroughly middle class and one, Daquin, was the grandson of a rabbi. Of the three, only he could be considered the courtier type. The other two were independent spirits, Fagon notoriously so. Vallot and Daquin were products of the Montpellier school of medicine, while Fagon received his training at the University of Paris. As we shall see, this implied far more than a sentimental division.

In point of time, Vallot was the first of our three premier médecins, assuming office in 1652 . He emerges from the memoirs of the time as a rather colourless and irresolute individual. Since he had charge of Louis XIV when the King was in his prime, his burden was relatively light. Only a case of typhoid fever (of which we shall say more later) and one of measles caused him any concern, although he was a bit nervous about the rather frantic life the pleasure-loving monarch was leading. But he consoled himself that there was 'no doubt of the purity of his life and of his chastity'. ${ }^{5}$ Since the King habitually read the Fournal, the wisdom of such absurdities was manifest.

Probably the most dramatic moment in Vallot's term as premier médecin came in 1664 during the fatal illness of the Queen Mother. Vallot, being of the Montpellier school, tended to rely on specifics, botanical or chemical. He was opposed by representatives of the Faculty of Paris, who looked upon phlebotomy as the basic remedy. A bitter debate ensued at the Queen Mother's bedside (a frequent occurrence at sickbeds if one may believe the memoirists) with the King acting as arbiter. Vallot won a resounding victory, but since the patient was afflicted with a fatal cancer of the breast no one could take much satisfaction in the case. A succession of charlatans was finally consulted in desperation, and after the most refined tortures the Queen Mother expired. ${ }^{6}$

Vallot died at the age of seventy-six in 1671 , still under violent attack as a charlatan by the formidable Faculty of Paris. He was succeeded by his nephew (by marriage), a man of good reputation but, to the dismay of the Faculty of Paris, also a graduate of Montpellier. Contemporary literature does not say as much about Daquin's medical skill as it does about his talents as courtier. Saint-Simon maintains he was a protégé of the King's last maîtresse en permanence, Madame de Montespan, which would certainly explain the coolness between Daquin and Madame de Maintenon after Montespan went the way of nearly all mistresses. ${ }^{7}$ Unfortunately for Daquin, as the King entered middle age he began to demand more and better medical attention than Daquin could give him. He was increasingly afflicted with gout, melancholy, and other ailments. However, Daquin might have survived these mounting pressures had it not been for his 
insatiable greed. He conducted his relations with the King on the generally sound principle that if you don't ask for what you want, you won't get it. But he went too far. In importuning the King for the Archbishopric of Tours for his son, Daquin finally caused the Grand Monarque to lose patience and he was ordered to retire from Court without delay. ${ }^{8} \mathrm{He}$ was given a pension of 6,000 livres to salve his feelings but apparently the disgrace was too much for him for he soon died, a broken man. 'With him died his family,' Saint-Simon unsorrowfully observed, 'which relapsed into nothingness.'

There was absolutely no doubt at Court about who would succeed Daquin. Long before the disgrace of Daquin, Maintenon had begun grooming her candidate for the position of premier médecin. Even though she was by this time married to the King, her position was not so impregnable as to permit a good friend of Montespan so close to the monarch. Her candidate was Guy-Crescent Fagon, easily the outstanding personality in the King's medical entourage. He was born in Paris in 1638 , the son of a minor functionary but nephew of the celebrated Guy de la Brosse, founder of the Jardin des Plantes. Shortly after getting his doctorate at Paris in 1664 , he became a professor of botany at the Jardin, which he helped make one of the leading scientific institutions of the world. ${ }^{10}$ In the 1670 os he was consulted on the precarious health of the young Duc de Maine, the second of the seven royal bastards born of Madame de Montespan. It was decided to take the duke to various health resorts, and Fagon was placed in charge. In the course of these peregrinations he became a close friend of the future wife of Louis XIV, then serving in relative obscurity as governess of the growing Montespan clan. Maintenon, who prided herself on her knowledge of things medical, was most impressed with Fagon and remained so to the end of her life. In subsequent years, as Madame de Maintenon became known among the Court gossips as 'Madame de Maintenant', Fagon's star brightened proportionally.

Maintenon employed all her talents in a long-range campaign to undermine Daquin. ${ }^{11}$ She would bring Fagon in for the slightest royal headache-just after Daquin had made his departure from the King's chamber. ${ }^{12}$ One night, when the King was suffering from a slight fever, he called out for Daquin, who unfortunately had retired for the night. By sheer coincidence, the faithful Fagon had taken a seat outside the King's room in case he was needed. A few months after this episode Daquin's request for the Archbishopric of Tours gave the King his pretext for dismissing his premier médecin.13

While there is no evidence that Fagon was a medical immortal, there can be no gainsaying the vast respect which he enjoyed in contemporary medical and lay circles. The Duc de Saint-Simon, ordinarily the implacable enemy of any 'creature' of Madame de Maintenon, called Fagon 'the most learned and skilful doctor' of his time. ${ }^{14} \mathrm{He}$ went on to say:

All the Court was respectful of Fagon, who, arbiter of the health of an old king and an allpowerful wife, herself sickly and even older than he, had risen several degrees above the ministers with a show of outward deference but with a temper so implacable and cruel that the person did not exist who dared to expose himself to it. ${ }^{15}$ 


\section{Leon Bernard}

Fagon - an ugly hunchbacked old man of middle-class background, asthmatic and subject to fits of apoplexy, a virtual recluse, ridiculous both in dress and manner of living-dominated French lords and French medicine alike, and sometimes even the King. ${ }^{16}$ The memoirists record only one individual who dared stand up to Fagon, a minor seigneur by the name of Brissac. This individual hated doctors as a class and saw no reason why he should make an exception of Fagon. Periodically, and often in the royal presence, he would engage in violent dispute with the premier médecin, causing the King to 'die of laughter and Fagon of rage'. Brissac's death in 17 I 3 removed from the scene the only man who 'dared attack Fagon in medical matters' ${ }^{17}$

Fagon exercised unparalleled domination over the medical profession. He was an implacable foe of charlatans, but he tended to look upon all doctors outside of the Faculty of Paris in this light, as he looked upon all remedies originating outside the Faculty as nostrums. Within four or five months after assuming office, he dissolved the 'Chambre Royale des Médecins Provinciaux,' a society organized by Vallot to protect provincial doctors from the despotism of the Faculty of Paris, and cut off drug supplies from its members. Finally, he prohibited graduates of Montpellier from practising in Paris without standing an examination before the Faculty of Paris. ${ }^{18}$

Fagon's reputation was so great that he was called to four royal deathbeds, of Charles II of Spain, of the exiled James II of England and of his successor William, and, of course, of Louis XIV. The circumstances in which he saw William are noteworthy. The year was I 70r and England and France were just beginning the long War of the Spanish Succession. Nevertheless, William called Fagon to his bedside and received him in the disguise of a village curé. Fagon, with no idea who his patient really was, calmly told him he was doomed and that he should prepare for death. ${ }^{19}$

According to some accounts, Fagon's stubbornness and conceit had grown so great by the time of Louis XIV's death that he was partly responsible for his master's death. It does seem clear that Fagon was very hesitant to acknowledge that the King was failing rapidly. Marshal de Villars, present during the monarch's last days, maintained that everyone saw the King's rapid decline, but Fagon assured Louis and Maintenon that there was nothing wrong that a light purging could not correct. ${ }^{20}$ The premier chirurgien, Maréchal, finally managed to muster enough courage to contradict Fagon and tell Maintenon that something was very wrong. ${ }^{21}$ But Louis XIV at the age of seventy-seven, a veteran of a lifetime of medical care which would have killed a lesser man long ere this, was beyond the ministrations of any seventeenth-century doctor. At his death, Fagon retired to his beloved Jardin des Plantes, Madame de Maintenon's praises ringing in his ears, ${ }^{22}$ and died two years later in 1717.

Thus far we have limited our remarks to the chief physicians of Louis XIV. The French monarch also employed a premier chirurgien-Félix from 1662 to I 703 and Maréchal from I 703 to I 7 I 5-plus the usual hierarchy of subordinate 
surgeons. As far as the medical men were concerned, the surgeons were of little count. The two sciences were separate from each other, as they had been since the Middle Ages. Between the Faculty of Medicine of the University of Paris and the independent Collège de Saint-Côme, the prime training-ground for French surgeons, there was only the bitterest acrimony. The Faculty of Medicine had long claimed sweeping jurisdiction over the training and licensing of surgeons demanding that surgical students register at the University and that their examinations be presided over by the medical doctors. ${ }^{23}$ In the view of the Faculty, surgeons were simply mechanics who sullied their hands while the physicians stood by and discoursed learnedly on the patient's ills. In the seventeenth century, medicine was as much a branch of rhetoric as a science.

In so far as the Court was concerned, this inherent bitterness between medicine and surgery was somewhat mitigated by the fact that until the appearance of Fagon late in the reign both the premier médecin and the premier chirurgien were pariahs in the eyes of the Faculty of Paris. Vallot and Daquin, having both received their training at Montpellier, could not afford a flagrantly condescending attitude towards Félix, a luminary and onetime head of Saint-Côme. It was more likely the other way round since no Parisian was in the seventeenth century apt to feel inferior to a provincial. However, this comparative amicability between Court medicine and surgery ended when Fagon became premier médecin in I693. Fagon, as one of the leaders of the Faculty of Paris, made no concessions to the representative of Saint-Côme at Court. We have seen how he had so completely intimidated the surgeon Maréchal by the time of Louis XIV's death that Maréchal did not dare express his opinion to the King or his wife.

Unfortunately for Fagon and his cohorts of the Faculty of Paris, time had passed them by. The day when the surgeon was hardly distinguishable in the popular mind from the barber was coming to an end. In I66o the Faculty had tried to deal the surgeons a death-blow by lobbying an edict which united barbers and surgeons in one guild, ${ }^{24}$ but this was ineffective and did little to retard the steady progress of the surgeons. By the end of Louis XIV's reign the surgical profession in France had entered its Golden Age. For well over a century, France dominated surgery until hardly any outstanding practitioner could be found in either the Old World or the New who was not French trained. ${ }^{25}$

Through no conscious effort of his own, Louis XIV played an important role in elevating the status of the surgeons. On 18 November 1686 , he submitted himself to the 'grande opération' for an anal fistula, one of the great events, medical or otherwise, of his long reign. The fistula began to trouble him in early 1686 , a matter of common knowledge apparently, since he and his doctors were deluged with suggestions on how to cope painlessly with this unpleasantness. Various medicinal waters were suggested and the royal doctors hopefully tried these on people afflicted with similar fistulas but with no results. Cauterization was resorted to, also, without success. Ligature was discussed and ruled out. The use of a caustic (a 'corrosive unguent') was deemed too slow and painful. Finally, the premier chirurgien, Félix, backed by Daquin, Fagon, and a 


\section{Leon Bernard}

Parisian consulting surgeon, persuaded the understandably reluctant King to accept surgery as the quickest and most permanent solution. ${ }^{26}$

While the alternatives were being ruled out one by one, Félix was reading everything that medical history had to say about anal fistulas. He had never performed the proposed operation before, but in the charity wards of Parisian hospitals he found a number of human guinea-pigs with similar anal fistulas. He operated on them, with what results is not recorded, but in any case by November 1686 he thought himself ready to perform the greatest operation of his career. He had meanwhile perfected a silver bistoury (to become known as 'le bistourie à la Royale') modelled on one described by Galen. ${ }^{27}$ At seven in the morning on 18 November, in the royal bedroom at Versailles, and in the presence of Louvois, Madame de Maintenon, Père La Chaise, Daquin, Fagon, Bessières (the Parisian consultant), a student of Félix, and four apothecaries (whose delicate function it was to hold the King still), the premier chirurgien gave 'two strokes with the bistoury and eight with the scissors', the latter to remove the 'callosities'. An hour later the patient was bled. The operation was declared a success and announced to a surprised and very sympathetic public.

Félix's triumph was a triumph for the entire surgical profession. The King's doctors had only stood silently by while a surgeon became a national figureand a very wealthy man. Before 1686 , surgeons had attracted little attention at Court; after the fistula operation they became important figures. ${ }^{28}$ Such a development would inevitably have repercussions through all ranks of French society. One contemporary writer even notes what a great inspiration the operation was to the young surgeons of France: they 'redoubled their efforts', he wrote. ${ }^{29}$

The surgeons of Louis XIV employed their scalpels on their monarch only once in his long reign. Their basic-and it would sometimes appear their only -function was phlebotomy. But one of the noteworthy things about the medical history of the reign is the King's reluctance to accept the contemporary dogma on the necessity of bleeding, a reluctance which often caused extreme dismay among his doctors. Vallot and Daquin deferred to the King's feelings and rarely proposed bleedings. Even after the King fell and dislocated an arm in r683-an accident which ordinarily called for an immediate extraction of blood-Daquin decided against such an operation because of the 'cruel vapours which this remedy excites in the King'. ${ }^{30}$

As a boy, when presumably he was not asked his opinions on such matters, Louis XIV was frequently bled. In his illness of $165^{8}$ he was bled eight times. In 1663 , two years after he became King in fact as well as in name, he was subjected to a bleeding which almost proved disastrous. Since, as we have previously noted, Louis XIV carefully perused his health journal, Vallot had no choice but to describe this bleeding as 'miraculous' in its results, but he added the ominous admission that 'the blood came out with such violence that we had trouble stopping it'. ${ }^{31}$ During the next twenty-three years the King was bled only once..$^{32}$

The emergence of Fagon as master of the royal health spelled a new 'hard' 206 


\section{Medicine at the Court of Louis XIV}

policy regarding bleeding. Fagon, as representative of the Faculty of Paris and thus thoroughly committed to phlebotomy, considered himself derelict in his duties if he did not bleed the King at least once a year, the much-recommended 'saignée de précaution'. ${ }^{33}$ The most absolute king of the seventeenth century could not stand up to the arguments of Fagon, who was doubtless backed by Madame de Maintenon, so confident of Fagon's judgement and so solicitous of her husband's health. Each spring there ensued a lively contest of wills between King and doctor, made all the more intense when the courtiers began openly to express sympathy for the King. Fagon complained ill-humouredly in I 705 of having to overcome not only the repugnance of the King but the 'ignorance' of the courtiers as well. ${ }^{34}$ Nevertheless, from 1703 on, Louis XIV never once evaded his spring bleeding. He became so convinced of the merits of phlebotomy that he even threatened to have his unwilling brother, the Duke of Orleans, bled by force. ${ }^{35}$ In the last few years of the reign, when the royal family was almost wiped out by a series of illnesses as mysterious as they were fatal, the royal doctors had extensive recourse to bleeding. The Bourbon line might well have expired then and there had not the Duchess of Ventadour locked herself in a room with the sole survivor, the infant soon to become Louis XV, placed him on mother's milk and refused to have him treated by the doctors. ${ }^{36}$

The social position of a doctor in the French Court was unique. That there was a gulf between the Court doctors and the courtiers no one can doubt. It is evident in the manner a memoirist, and dyed-in-the-wool aristocrat, like SaintSimon curtly refers to 'Fagon' or 'Félix'. Nevertheless, the Court doctor was the only individual of middle-class background outside of the Clergy who enjoyed a measure of social acceptance from 'les Grands'. For the most part, relations between courtiers and doctors were easy and friendly. The fact that the King's surgeon gave a 'fort jolie collation' for a younger member of the royal family is taken as a matter of course. ${ }^{37}$ In the great cortège of more than six hundred courtiers and attendants sent to Lyons to escort a future princess to Versailles, the royal doctor and surgeon were honoured with the third carriage. ${ }^{38}$

The positions of chief doctor and chief surgeon carried enormous prestige and financial reward. These men were classified among the 'grands officiers' of the royal household. Sooner or later they could confidently expect to be ennobled by the King. ${ }^{39}$ Whether or not the premier médecin emanated from the august Faculty of Paris (the King could choose his physicians from any medical faculty or from none at all), he had to be received as a superior by the Dean of the Faculty and enjoyed full rights to practise in Paris. He had jurisdiction of a sort over all French medicine, pharmacy, and mineral waters, was Superintendent of the Jardin des Plantes, and appointed city officials roughly comparable to coroners. ${ }^{40}$

As compensation, the premier médecin of Louis XIV received a salary of from 40,000 to 45,000 livres, roughly equivalent to $£^{25,000}$ today. ${ }^{41}$ But that was only the beginning. Louis XIV expected his sick courtiers to seek out his 


\section{Leon Bernard}

own doctor in much the same manner he expected Mansard to be appealed to in architectural matters or Lebrun in problems of interior decoration. ${ }^{42}$ This being the case the premier médecin and his subordinates ${ }^{43}$ never lacked for patients. A course of treatment or a drug administered to the King was likely immediately to become high fashion. After the fistula operation, the surgeon Félix was deluged with requests from courtiers for a similar operation, althought some dishonest souls tried to pass off simple haemorrhoids for the genuine article. ${ }^{44}$

In one respect, the office of Court doctor in the ancien régime would be roughly comparable today to a position of personal physician to a great financier. In those days one received 'tips' not on the market but on 'charges' - offices. The number of venal Court offices ran into the thousands. Most of them were sinecures, carrying with them impressive titles, little work, and a nice annual payment from the Royal Treasury or some other source. Once purchased, such an office was in every sense of the word private property. The value of these offices was often subject to sharp fluctuations. A person on the 'inside', like a Court doctor, was in an excellent position to make money. The surgeon Félix purchased the office of Premier Valet de garde-robe in 1690 for 75,000 livres; in I 697 he sold the same office for I I 5,000 livres, having enjoyed in the intervening years a considerable annual revenue. ${ }^{45}$

If one were fortunate, it was sometimes not even necessary to finance these purchases through one's own funds since Louis XIV was extremely openhanded to those in his medical service. When Fagon had a stone removed from his bladder in I 70 I, the King was so sympathetic that he bestowed a 100,000-livres office on Fagon's son to cheer the patient. ${ }^{46}$ The surgeon Maréchal realized 50,000 livres in 1706 from the sale of an office given him in that year by the King. A few years later he received a gift of 30,000 livres as a reward for a successful bladder operation performed on the King's natural son, the Comte de Toulouse. ${ }^{47}$ One of the more unusual of these gifts was that bestowed upon the consultant Bessières in 169o; he was given the Abbey of Saint-Clément in Metz, worth some 6,00o livres annually.

The most spectacular single example of royal largesse came after the fistula operation. The doctors and others involved shared over 500,000 livres, thus making it surely the most expensive operation in surgical history. The four apothecaries who had held the King quiet received 12,000 livres each, Daquin and Fagon got 100,000 and 80,000 livres respectively for standing by, while Félix, the man of the hour, was given 150 ,00o livres and an estate in the park of Versailles valued at more than I50,00o livres, formerly the home of a financier whose residence had been shifted to the Bastille because of certain financial indiscretions. ${ }^{48}$

We have seen how the removal of the King's fistula caused this operation to become high fashion among certain courtiers at Versailles. The same result could be expected whenever the King or members of his family adopted anything new. Of particular interest for us in this study is the popularization, for better or for worse, of new drugs as a consequence of their use by the royal 208 


\section{Medicine at the Court of Louis XIV}

family, a tendency which made the medical opinions of a Vallot or a Fagon of national, and even European, importance. During the reign of Louis XIV, three drugs, one very old one and two importations from the New World, came into widespread use simply because they had been tried by the royal family and found effective: antimony, ipecac, and cinchona.

After the question of the circulation of the blood, the subject of greatest controversy in seventeenth-century medicine was probably antimony. Dear to the hearts of both ancient and medieval practitioners, antimony had come under suspicion in the sixteenth century and in 1566 had been banned in France by Parliament. Nevertheless, its advocates, centred in the Faculty of Montpellier but including even a few men from Paris, remained both vocal and numerous. They discovered that the law could be successfully evaded by prescribing white wine administered from cups of antimony. ${ }^{49}$

The controversy was still raging in 1658 when the twenty-year-old Louis XIV contracted what may have been typhoid fever. For fifteen days his life was in the balance. ${ }^{50}$ Four Gourt doctors (Vallot, Esprit, Daquin, and Yvelin) laboured to save his life by repeated bleedings and purges. Finally, a consultant from Paris, by name Guénaud, arrived and recommended the use of antimony. Reluctantly, and more or less as a last resort, Cardinal Mazarin consented. Louis XIV was given one ounce of antimony in white wine and purged twentytwo times. ${ }^{51}$ Despite this he recovered and antimony was given the credit. For the champions of antimony, the King's return to health was of secondary importance. What counted was that the life of the most important monarch in Europe had apparently been saved by antimony. From that moment the future of the drug was assured, although Parliament did not formally rehabilitate it until 1666. In the literature of Louis XIV's time, antimony, or the 'vin émétique', takes on an importance second only to bleedings and purges. ${ }^{52}$

A second drug whose popularization had to await royal acceptance was ipecac. Here the central figure is a foreign practitioner named Adrien Helvétius. This large and cheerful Dutchman arrived in Paris in 1684 and became a naturalized Frenchman almost on arrival. Although he was ostracized by the members of the Faculty of Paris as an empirique, he had no trouble collecting a fashionable and influential practice, while at the same time doing much good work among the poor. ${ }^{53} \mathrm{His}$ forte was curing patients pronounced incurable by the Faculty, a habit which could hardly have endeared him to his colleagues when he was successful, as he not infrequently was.

Soon after his arrival in Paris, Helvétius came into possession of a large amount of the South American herb ipecacuanha, a product well known to the druggists but which had not as yet found significant medical application. With it Helvétius cured the Dauphin of a 'bloody flux'. Louis XIV gratefully authorized Helvétius to conduct experiments among the poor at the Hôtel-Dieu for its possible use against dysentery. On the basis of these experiments, Helvétius was given a monopoly over the sale of ipecac for a four-year period as well as a handsome gift from the King. ${ }^{54}$ The remedy became known as the 'remède d'Helvétius' or 'poudre émétique'. Although Helvétius was never accepted by 


\section{Leon Bernard}

the members of the Faculty, contemporary lay writers at least regarded him as the leading authority on dysentery and allied ailments. Marshal de Villars, in Italy with a French army, when afflicted with dysentery sent off to Paris for Helvétius's remedy and obtained excellent results. ${ }^{55}$ In I 7 I4 Helvétius made a dramatic trip to Madrid at the request of the Queen of Spain, dying from what appeared to be dysentery. Louis XIV furnished him with special post-chaises and an escort for the journey, but he arrived only in time to take part in the autopsy. ${ }^{56}$ At the death of Louis XIV, Helvétius's reputation was thus well established. He became one of the doctors of Louis XV, was ennobled in I 724, and died three years later. His grandson was the noted philosophe, Claude Helvétius, who had as much trouble with the theologians of the University of Paris as his grandfather had had with the Faculty of Medicine.

Still another pharmaceutical product the King popularized was cinchona or 'Peruvian bark'. Introduced in Europe in the first half of the seventeenth century, it soon became the centre of a controversy as much religious as medical. In England, it was commonly referred to as 'Cardinal's Powder' or 'Jesuit Powder'. Many Protestants apparently preferred death to a dose of a drug as repugnant in its taste as in its Catholic origins. Nevertheless, by 1677 it was listed in the London Pharmacopaia under the term 'Cortex peruanus', and no less a personage than Thomas Sydenham was advocating its use as a specific for fevers. ${ }^{57}$

The popularization of cinchona in France centres round an Englishman Robert Tabor or Talbor, who was knighted by Charles II for curing his malaria. In France he was invariably referred to as 'l'Anglais' and his remedy as the 'remède anglais'. He arrived in Paris in 1678 or 1679 . His success was immediate despite the opposition of the Faculty of Paris, which dismissed him as a flagrant charlatan.

For two years, Talbot and his remedy were the subject of great controversy. Cardinal de Retz on his deathbed asked repeatedly for 'l'Anglais', but his attending physician of the Faculty, Guillaume Petis, refused to permit Talbot to come into the case until the very last moment. When he finally arrived, he acidly remarked that his skills did not include the resurrection of the dead. ${ }^{58} \mathrm{~A}$ few months later a somewhat similar scene took place round the deathbed of an equally distinguished personage, the Duc de la Rochefoucauld. Had the Duke been less seriously ill, he would have undoubtedly availed himself of the opportunity to phrase some of his immortal maxims on the vagaries of the human species. Three contending groups formed round his bed: representatives of the Faculty, 'l'Anglais' and his backers, and a certain unidentified 'Brother Angel'. This time, Talbot won the debate, which turned out to be unfortunate for him because after a very promising recovery $\mathrm{La}$ Rochefoucauld suffered a relapse and died within a few hours. ${ }^{59}$

La Rochefoucauld's death was only a temporary setback for Talbot. In October the Dauphin fell ill with a high fever. He was helped by a dose of the 'remède anglais' administered not by Talbot but by a certain Philippe who lived with Talbot and had apparently acquired the formula. ${ }^{60}$ But a few weeks later 
the Dauphin had a relapse and this time the King called in Talbot personally. " "L'Anglais",' Madame de Sévigné wrote excitedly, 'has promised the King ... so positively to cure Monseigneur in four days ... that if he does not succeed I think they will throw him out of the window.' ${ }^{61}$ Louis XIV ordered Talbot to prepare his remedy in his presence, as the premier médecin, Daquin, watched in suppressed rage. This time all went well for Talbot. The Dauphin recovered quickly. After this episode the 'remède anglais'-powdered cinchona bark in wine-became the 'miracle drug' of the late seventeenth century and one of the staple remedies of Louis XIV. ${ }^{62}$ If he had been of a mind to do so, the Grand Monarque could well have added one more item to his res gestae: the popularization of cinchona. ${ }^{63}$

\section{REFERENCES}

I. Monmerque, M. (ed.) (1862-6). Lettres de Madame de Sévigné, Les Grands Ecrivains de la France, ed. Ad. Regnier. Paris, 3, 497.

2. Le Ror, J. A. (ed.) (1862). Fournal de la Santé du Roi Louis XIV. Paris, 219.

3. Soulíté et al. (eds.) (1854-6o). Fournal du Marquis de Dangeau. Paris, 4, 389.

4. Two doctors preceded this trio: Cousinot from I643 to 1646 and Vaultier from I646 to 1652. Because of their short terms of office, coming before the King arrived at maturity, we are disregarding them in this study.

5. Fournal de la Santé du Roi, 27.

6. Mighaud and Poujoulat (eds.) (1854). Mémoires de Madame de Motteville, Nouvelle Collection des Mémoires relatifs à l'Histoire de France. Paris, $542-63$.

7. DE Boislisle (ed.) (1879-1923). Mémoires de Saint-Simon, Les Grands Ecrivains de la France, ed. Ad. Regnier. Paris, r, 287.

8. De Borslisle, op. cit., Dangeau, 4, 390 .

9. Saint-Simon, 3, 85 .

io. Mettle r, Gegilia C. (1947). History of Medicine. Philadelphia, 855.

I1. Saint-Simon, $\mathrm{r}, 287$.

12. Mighaud and Poujoulat (eds.) (1854). Mémoires de l'Abbé de Choisey, Nouvelle Collection des Mémoires relatifs à l'Histoire de France. Paris, 6 rg.

13. Mighaud and Poujoulat, op. cit.; Saint-Simon, r, 284.

14. 'Additions inédites du Duc de Saint-Simon,' Dangeau, 1 5, 228; Saint-Simon, r, 288.

15. Dangeau, 15, 229.

16. The description of Fagon is drawn from Dangeau, 4, 390, and Saint-Simon, 8, 95.

17. Dangeau, 14, 34I; Saint-Simon, 23, 277.

18. Editor's note, Saint-Simon, 1, 289.

19. Saint-Simon, ro, rzo.

20. De Vogue (ed.) (1884-1904). Mémoires du Maréchäl de Villars, Société de l'Histoire de France. Paris, 4, 55.

21. Dangeau, 16, 12, 97-8.

22. GefFroy, A. (ed.) (1887). Madame de Maintenon d'après sa correspondance authentique. Paris, 2, 377.

23. Franklin, Alfred. La Vie Privée d'Autrefois. Les Chirugiens. Paris, I44.

24. Ibid., 129 .

25. Mettler, History of Medicine, 864, 889. 


\section{Leon Bernard}

26. Le Ror, J. A. La Grande Opération faite au Roi Louis XIV, en I686, 27. Ibid.

Pièces Justificatives, No. 5, Fournal de la Santé du Roi, 389-9o.

28. Franklin, La Vie Privée, 144 .

29. Mémoires de Choisey, 620.

30. Fournal de la Santé du Roi, 159.

31. Ibid., 86.

32. Phlebotomy as practised in the seventeenth century was anything but a minor operation. The memoirs of the time contain innumerable allusions to injuries and even fatalities caused by surgeons who 'missed', i.e., struck an artery. Saint-Simon suffered a serious injury in 1704 from a maladministered bleeding. Saint-Simon, 12, 49.

33. In theory it was the duty of the chief surgeon, Félix, to perform these operations. But Félix had lost his skill and nearly killed a courtier in 1689. He even 'missed' the King once. So recourse was had to other surgeons until the very adept Maréchal became chief surgeon in I 703. Saint-Simon, 8, 241.

34. Fournal de la Santé du Roi, 280.

35. Dangeau, 8, I19.

36. D'HA Usso n vil Le, La Duchesse de Bourgogne et l'Alliance Savoyarde sous Louis XIV. Paris, n.d. 4, $4 \mathrm{I} 6$. It is hard to say which she feared the most; the doctors or rumoured poisoners.

37. Dangeau, 4, 380 .

38. D'Hauss ONVille, I, 201.

39. Raynaud maintains that the office of premier médecin carried with it an automatic countship, transferable to one's heir, but this would appear doubtful. Raynaud (1867). Les Médecins au temps de Molière. Paris, 142.

40. Raynaud: op. cit.; Franklin, La Vie Privée, II, I9I.

4I. Fran KLIN, op. cit.; Saint-Simon, I, 284 .

42. Saint-Simon, 15,41 .

43. The royal medical service included, in addition to the premier médecin, a médecin ordinaire, eight doctors serving en quartier (three months each year), an anatomist, a médecin mathématicien, four chemists, a botanist, and a small army of consultants. Franklin, La Vie Privée, Ir, 193. Each member of the royal family had a similar though less elaborate organization.

44. Fournal de la Santé du Roi, 404.

45. Dangeau, 3, 231; 6, 203.

46. RAYNAUD, op. cit., 8, 247.

47. FranKLIN, op. cit., 14, 38 .

48. Fournal de la Santé du Roi, 404 .

49. Met tle R, History of Medicine, 203.

50. Mémoires de Madame de Motteville, 465 .

51. Raynaud, Les Médecins au temps de Molière, 206. Mme de Motteville in her Mémoires (465) says that two 'vins émétique' were administered.

52. Met TLER, History of Medicine, 202-3. One notable voice raised in opposition to the 'chemists' was Guy Patin, who chose to attribute the King's recovery to 'nine good bleedings' rather than to antimony. RAYNAUD, Les Médecins au temps de Molière, 207. On the misanthropic Patin, see F. R. PAGKard (1922), Guy Patin and the medical profession in Paris in the seventeenth century, Ann. Med. Hist., 4, pp. I 36-65; 21 5-40;357-85. 


\section{Medicine at the Court of Louis XIV}

53. Saint-Simon, 8, 92-3.

54. Ibid.; RAYNAUD, Les Médecins au temps de Molière, 219.

55. Saint-Simon, 8, 93; RAY NAUd, Les Médecins au temps de Molière, 219.

56. Mémoires de Villars, 2, 5 .

57. Dangeau, 15, 72, 90.

58. Lettres de Madame de Sévigné, 5, 560.

59. Ibid., 6, 309-I I.

6o. Ibid., 7, 104.

6r. Ibid., 128.

62. Fournal de la Santé du Roi, i73; Ezechier Spanfeim, (1882). Relation de la Cour de France en I6go. Paris, 434.

63. Siegel, R. E., and Poynter, F. N. L. (rg6r). Robert Talbor, Charles II, and cinchona. A contemporary document. Med. Hist., 6, 82-5. 